\title{
Correlational Study on the Relationship Between Students' Metacognition Development and Students' Learning Result
}

\author{
Ikhya Ulumudin*, Etty Sofyatiningrum, Nur Listiawati, Asma Aisha \\ Center for Policy Research \\ Research, Development, and Book Board - MoEC \\ Jakarta, Indonesia \\ *ikhya.ulumudin@kemdikbud.go.id, etty.sofia@gmail.com, n.listiawati07@gmail.com, asmaisha.87@gmail.com
}

\begin{abstract}
Metacognition can help students improve the competencies needed for them to develop high order thinking skill, which will help in the global competition. However, students' metacognitive skill has yet to receive serious attention from teachers. This study aims to find out the correlation between developing students' metacognition and their learning results in Math, Reading, and Science. The method used was the quantitative method with correlational analysis using secondary data from 2018 PISA result consisting of questionnaire and scores in Math, Reading, and Science test. The total samples of students were 11.986 students. The hypothesis was tested and analyzed using non-parametric method, through Spearman rank correlation. The result showed that there was a positive and significant correlation between developing students' metacognition and the learning result in the subjects of Math, Science, and Reading. However, it was a weak correlation. This was partly due to many Indonesian students thinking that intelligence was something that could not be changed, so they felt less motivated to improve their intelligence.
\end{abstract}

Keywords-PISA, metacognition, math, reading, science

\section{INTRODUCTION}

The most essential competency needed in the 21 st century is higher order thinking skill (HOTS). This competency is needed in preparing students to face global challenges so they can compete with other countries. However, the higher order thinking skills in Math, Science, and Reading showed by Indonesian students compared to other countries is quite low and alarming. This could be seen from the Program for International Students Assessment (PISA) result in 2018, which showed that Indonesia was far behind other participant countries, and even had scored lower than other South East Asian countries such as Thailand, Malaysia, and Vietnam. The result also showed a decline compared to the result in 2015. In 2015, Indonesia's PISA score for Math had been 386, while in 2018 it declined to 379. Score for Science also declined from 403 to 396, and Reading's score declined from 397 to 371 [1]. This showed a 7-point decline for Math and Science, and a significant 26-point decline for Reading.
Reflecting on the results of PISA 2018, there is still a lot of work to be done to improve the quality of Indonesian education. One of the efforts is to improve students' metacognition through the learning process carried out by teachers. A study conducted by Hattie [2] from the Education Endowment Foundation showed that metacognition strategies had a great impact on learning outcomes. The metacognition strategy also did not require high funding. Other research stated that if metacognition awareness is realized, a person could lead one's mind by designing, monitoring, controlling and assessing what one is learning [3].

Metacognition, or "thinking about thinking" is the knowledge and understanding we have of our own cognitive process and the ability we have to study our thinking and monitor what happens [4]. According to Desmita [5], metacognition is the knowledge and awareness about a process of cognition or the knowledge about the mind and how it works. Metacognition is a way of thinking involving components of function planning, self-monitoring, and selfevaluation [5]. According to Amri [6], metacognition is awareness of thinking about what is known and what is not known.

Another opinion states that metacognitive awareness is defined as information from its own cognitive aspects, and planning, organizing and monitoring one's learning situation to increase success (Schraw \& Dennison, 1994 in Koc and Kuvac, [7]). Students must be able to determine learning targets by defining what they should know more about the assignments they are working on. They must be able to plan their learning and choose appropriate learning strategies. In other words, they must be able to decide on an action plan to achieve the targets they set. Finally, they must be able to monitor and assess whether their goals are met (Hmelo-Silver, 2004 in Koc and Kuvac [7]).

Metacognition has four characteristics, which are: (1) knowing the goals to be achieved through the process of thinking seriously, (2) choosing a strategy to achieve goals, (3) observing the development process, self-knowledge to see 
whether the chosen strategy is right, (4) evaluating the results, whether the objectives have been achieved [8].

However, the reality is not all students can apply their metacognition awareness properly in solving problems. There is different metacognition awareness between students who solve a problem correctly and students who make mistakes in solving problems [9]. Most of Indonesian students have not yet realized the importance of metacognition strategies. Bulu [10] found that there were still a number of students who had difficulty to use metacognition when faced with problems.

Therefore, in order to improve students' competence in Indonesia, teachers need to foster student metacognition in every learning process and activity. Some ways to develop students' metacognitive skill in the learning process require teachers to set clear goals in the learning process and inform students what will be learned. In addition, teachers need to inform students their weaknesses and strengths in a subject matter and teach them how to improve competencies they are still lacking.

Students' metacognition ability has not received much serious attention from teachers and stakeholders, when in fact metacognitive skill can help students improve the competencies needed in developing higher-level thinking skills to compete with the global world. Research results of Ovan and Nugroho [11] revealed that low metacognition students have poor Math literacy skills, moderate metacognition students have quite good Math literacy skills, and high metacognition students have excellent Math literacy skills. For that reason, this study aims to: (i) find out the correlation between developing students' metacognition and their Math learning outcomes; (ii) find out the correlation between developing students' metacognition and their Reading learning outcomes; (iii) find out the correlation between developing students' metacognition and their Science learning outcomes.

The hypothesis formulation in this study includes: (i) There is a positive and significant correlation between developing students' metacognition and their Math learning outcomes; (ii) There is a positive and significant correlation between developing students' metacognition and their Reading learning outcomes; (iii) There is a positive and correlation between developing students' metacognition and their Science learning outcomes.

\section{Methods}

\section{A. Research Methods}

This research used quantitative methods, which include correlational research. Correlational research is intended to find out the relationship between two or more variables.

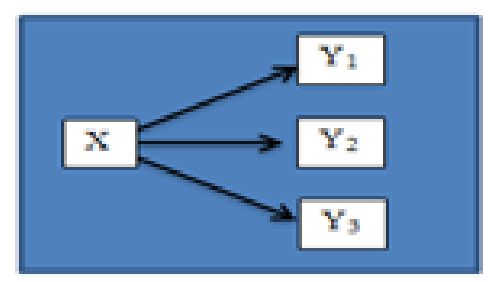

Fig. 1. Constellation problem.

Figure 1 show there are four variables (constellation problem) in this study, consisting of one independent variable and three dependent variables. The independent variable is developing student metacognition $(\mathrm{X})$, while the dependent variables are Mathematics learning outcomes (Y1), Reading learning outcomes (Y2), and Science learning outcomes (Y3).

The data used in this research are secondary data from the PISA website page consisting of the result of filled-out questionnaires and students' PISA scores from all participating countries in 2018. The downloaded secondary data is in the form of SPSS format with the name 'Student questionnaire data file' [12]. The file contains the results of student questionnaires and Math, Reading, and Science test scores.

The developing students' metacognition variable was taken from the questionnaires consisting of seven items: (i) The teacher sets clear goals for our learning; (ii) The teacher asks questions to check whether we have understood what was taught; (iii) At the beginning of a lesson, the teacher presents a short summary of the previous lesson; (iv) The teacher tells us what we have to learn; (v) The teacher gives me feedback on my strengths in this subject; (vi) The teacher tells me in which areas I can still improve; (vii) The teacher tells me how I can improve my performance. The options for items number 1 to 4 are Every lesson (score 4), Most lessons (score 3), Some lessons (score 2) Never or hardly ever (score 1). The options for items number 5 to 7 are Never or almost never (score 1), Some lessons (score 2), Many lessons (score 3), and Every lesson or almost every lesson (score 4). The variables of Mathematics learning outcomes, reading learning outcomes, and Science learning outcomes are taken from the average value of each of these variables [1]

The sample were Indonesian students aged 15 who took part in PISA in 2018. The number of samples was 12,098 students, but after data cleaning, the number became 11,986 students. Prerequisite data analysis used normality and linearity test, while the analysis of hypothesis testing used nonparametric Spearman rank.

The hypothesis testing of this research is as follows. Hypothesis 1: H0: There is no correlation between developing students' metacognition and Mathematics learning outcomes. H1: there is a correlation between developing students' metacognition and Mathematics learning outcomes.

Hypothesis 2: H0: There is no correlation between developing students' metacognition and Reading learning 
outcomes. H1: there is a correlation between developing students' metacognition and Reading learning outcomes.

Hypothesis 3: H0: There is no correlation between developing students' metacognition and Science learning outcomes. H1: there is a correlation between developing students' metacognition and Science learning outcomes.

\section{B. Data Description}

Data from the study consisted of one independent variable and three dependent variables. The independent variable is developing student metacognition $(\mathrm{X})$, while the dependent variables are Mathematics learning outcomes (Y1), Reading learning outcomes (Y2), and Science learning outcomes (Y3). A data description of each of these variables will be presented in the following paragraph.

The data collection technique for the learning process in developing student metacognition variable $(\mathrm{X})$ was done using a questionnaire sourced from PISA 2018, with only seven questions related to the variable $\mathrm{X}$ were taken. After data cleaning, total respondents were 11,986 students.

\section{RESULTS AND DISCUSSION}

The result of data processing and analyzing are as follows. The lowest score is 1.00 and the highest is 4.00. The mean value is 2.03 , the median is 2.00 , the mode is 2.29 , and the standard deviation is 0.42 .

The frequency distribution of variable $X$ and its steps are presented as follows: (i) Determining the range of variable $\mathrm{X}$ by subtracting the lowest value from the highest value. The highest value of variable $\mathrm{X}$ is 4 and the lowest is 1 , so the range is 3; (ii) Determining the number of classes using the equation $1+3.3 \log (n)$ with a value $(n)$ of 11,986 , so the number of classes is 14; (iii) Determining the class length by dividing range by the number of classes, so the class length is 0.21 .

TABLE I. FREQUENCY DISTRIBUTION OF THE DEVELOPING STUDENTS' METACOGNITION VARIABLE

\begin{tabular}{|l|l|l|l|l|}
\hline No & \multicolumn{1}{|c|}{ Interval } & Frequency & Percentage & $\begin{array}{l}\text { Cumulative } \\
\text { Percentage }\end{array}$ \\
\hline 1 & $1,00-1,21$ & 203 & 1,69 & 1,69 \\
\hline 2 & $1,22-1,43$ & 1159 & 9,67 & 11,36 \\
\hline 3 & $1,44-1,65$ & 782 & 6,52 & 17,89 \\
\hline 4 & $1,66-1,87$ & 2746 & 22,91 & 40,80 \\
\hline 5 & $1,88-2,09$ & 1708 & 14,25 & 55,05 \\
\hline 6 & $2,10-2,31$ & 3225 & 26,91 & 81,95 \\
\hline 7 & $2,32-2,53$ & 863 & 7,20 & 89,15 \\
\hline 8 & $2,54-2,75$ & 900 & 7,51 & 96,66 \\
\hline 9 & $2,76-2,97$ & 164 & 1,37 & 98,03 \\
\hline 10 & $2,98-3,19$ & 139 & 1,16 & 99,19 \\
\hline 11 & $3,20-3,41$ & 24 & 0,20 & 99,39 \\
\hline 12 & $3,42-3,63$ & 33 & 0,28 & 99,67 \\
\hline 13 & $3,64-3,85$ & 5 & 0,04 & 99,71 \\
\hline 14 & $3,86-4,00$ & 35 & 0,29 & 100,00 \\
\hline SUM & 11.986 & 100 & 100 \\
\hline
\end{tabular}

Table 1 shows the distribution of Math scores of Indonesian students on PISA 2018. For the Math learning outcome variable (Y1), data were collected from the 2018 PISA test. After data cleaning, the total respondents were 11,986 students. The result of data processing and analyzing are as follows. The lowest score is 129.56 and the highest is 720.96 . The mean value is 401.66 , the median is 396.15 , mode is 435.44 , and the standard deviation is 80.57 . The frequency distribution of Mathematics learning outcomes and its steps are presented as table 2 follows.

TABLE II. FREQUENCY DISTRIBUTION OF THE MATH LEARNING OUTCOMES VARIABLE

\begin{tabular}{|l|l|l|l|l|}
\hline No & \multicolumn{1}{|c|}{ Interval } & Frequency & Percentage & $\begin{array}{l}\text { Cumulative } \\
\text { Percentage }\end{array}$ \\
\hline 1 & $122,00-164,99$ & 9 & 0.08 & 0.08 \\
\hline 2 & $165,00-207,99$ & 46 & 0.38 & 0.46 \\
\hline 3 & $208,00-250,99$ & 197 & 1.64 & 2.10 \\
\hline 4 & $251,00-293,99$ & 665 & 5.55 & 7.65 \\
\hline 5 & $294,00-336,99$ & 1682 & 14.03 & 21.68 \\
\hline 6 & $337,00-379,99$ & 2473 & 20.63 & 42.32 \\
\hline 7 & $380,00-422,99$ & 2464 & 20.56 & 62.87 \\
\hline 8 & $423,00-465,99$ & 1900 & 15.85 & 78.73 \\
\hline 9 & $466,00-508,99$ & 1285 & 10.72 & 89.45 \\
\hline 10 & $509,00-551,99$ & 767 & 6.40 & 95.85 \\
\hline 11 & $552,00-594,99$ & 359 & 3.00 & 98.84 \\
\hline 12 & $595,00-637,99$ & 119 & 0.99 & 99.83 \\
\hline 13 & $638,00-680,99$ & 18 & 0.15 & 99.98 \\
\hline 14 & $681,00-723,99$ & 2 & 0.02 & 100.00 \\
\hline SUM & & 11,986 & 100 & 100 \\
\hline
\end{tabular}

For the Reading learning outcome variable (Y2), data were collected from the 2018 PISA test. After data cleaning, the total respondents were 11,986 students. The result of data processing and analyzing are as follows. The lowest score is 181.00 , and the highest is 666.09 . The mean value is 390.47 , the median is 385.68, mode is 391.93, and the standard deviation is 79.21. The frequency distribution of Reading learning outcomes and its steps are in table 3.

TABLE III. FREQUENCY DISTRIBUTION OF THE READING LEARNING OUTCOMES VARIABLE

\begin{tabular}{|l|l|l|l|l|}
\hline No & \multicolumn{1}{|c|}{ Interval } & Frequency & Percentage & $\begin{array}{l}\text { Cumulative } \\
\text { Percentage }\end{array}$ \\
\hline 1 & $180,00-214,99$ & 46 & 0.38 & 0.38 \\
\hline 2 & $215,00-249,99$ & 252 & 2.10 & 2.49 \\
\hline 3 & $250,00-284,99$ & 725 & 6.05 & 8.53 \\
\hline 4 & $285,00-319,99$ & 1351 & 11.27 & 19.81 \\
\hline 5 & $320,00-354,99$ & 1867 & 15.58 & 35.38 \\
\hline 6 & $355,00-389,99$ & 1984 & 16.55 & 51.94 \\
\hline 7 & $390,00-424,99$ & 1922 & 16.04 & 67.97 \\
\hline 8 & $425,00-459,99$ & 1445 & 12.06 & 80.03 \\
\hline 9 & $460,00-494,99$ & 1098 & 9.16 & 89.19 \\
\hline 10 & $495,00-529,99$ & 707 & 5.90 & 95.09 \\
\hline 11 & $530,00-564,99$ & 371 & 3.10 & 98.18 \\
\hline 12 & $565,00-599,99$ & 168 & 1.40 & 99.58 \\
\hline 13 & $600,00-634,99$ & 43 & 0.36 & 99.94 \\
\hline 14 & $635,00-669,99$ & 7 & 0.06 & 100.00 \\
\hline SUM & & 11,986 & 100 & 100 \\
\hline
\end{tabular}


For the Science learning outcome variable (Y3), data were collected from the 2018 PISA test. After data cleaning, the total respondents were 11,986 students. The result of data processing and analyzing are as follows. The lowest score is 195.50, and the highest is 684,95 . The mean value is 414.15 , the median is 408.66 , mode is 413.55 , and the standard deviation is 70.09. The frequency distribution of Science learning outcomes and its steps are presented table 4 as follows

TABLE IV. FREQUENCY DISTRIBUTION OF THE SCIENCE LEARNING OUTCOMES VARIABLE

\begin{tabular}{|l|l|l|l|l|}
\hline No & \multicolumn{1}{|c|}{ Interval } & Frequency & Percentage & $\begin{array}{l}\text { Cumulative } \\
\text { Percentage }\end{array}$ \\
\hline 1 & $195,00-229.99$ & 20 & 0.17 & 0.17 \\
\hline 2 & $230,00-264.99$ & 66 & 0.55 & 0.72 \\
\hline 3 & $265,00-299.99$ & 345 & 2.88 & 3.60 \\
\hline 4 & $300,00-334.99$ & 1049 & 8.75 & 12.35 \\
\hline 5 & $335,00-369.99$ & 1969 & 16.43 & 28.78 \\
\hline 6 & $370,00-404.99$ & 2287 & 19.08 & 47.86 \\
\hline 7 & $405,00-439.99$ & 2169 & 18.10 & 65.95 \\
\hline 8 & $440,00-474.99$ & 1690 & 14.10 & 80.05 \\
\hline 9 & $475,00-509.99$ & 1185 & 9.89 & 89.94 \\
\hline 10 & $510,00-544.99$ & 700 & 5.84 & 95.78 \\
\hline 11 & $545,00-579.99$ & 372 & 3.10 & 98.88 \\
\hline 12 & $580,00-614.99$ & 112 & 0.93 & 99.82 \\
\hline 13 & $615,00-649.99$ & 20 & 0.17 & 99.98 \\
\hline 14 & $650,00-684.99$ & 2 & 0.02 & 100.00 \\
\hline SUM & 11,986 & 100 & 100 \\
\hline
\end{tabular}

\section{A. Prerequisite Test}

Before conducting the hypothesis test, the prerequisite test was performed first, which included normality test and linearity test. The results of both tests using SPSS program will be presented as follows.

Normality test was conducted on all of the independent and dependent variables. The normality test criteria for each variable are seen from the values in the significance column (Sig.). If the significance value obtained is greater than alpha $(5 \%)$, it means the sample comes from a normally distributed population. If the significance value obtained is smaller than alpha, it means the sample comes from populations that are not normally distributed.

The normality test result using SPSS showed all 4 variables had a significance value of 0.00 . This is smaller than 0.05 , which means the four variables-developing student metacognition (X), Mathematics learning outcomes (Y1), Reading learning outcomes (Y2), and Science learning outcomes (Y3) — data are not normally distributed.

Linearity test showed result of deviation from linearity value of 0,00 . This means the significance was lower than 0,05 , so it can be concluded that no linearity among the relationship between developing student metacognition and Mathematics learning outcomes (Y1), between developing student metacognition and Reading learning outcomes (Y2), and between developing student metacognition and Science learning outcomes (Y3)
Based on the results of the prerequisite test using the normality and linearity test, the hypothesis test in this study used the non-parametric correlation test using Spearman Rank Correlation.

\section{B. Hypothesis Test}

This study aims to examine the correlation between developing student metacognition skill and learning outcomes in Mathematics, Reading, and Science. The hypothesis test used nonparametric correlations (Spearman rank). The basis for decision-making is if the significance value $<0.05$ then it correlates ( $\mathrm{H} 0$ is rejected or $\mathrm{H} 1$ is accepted) and if the significance value $>0.05$ then it doesn't correlate ( $\mathrm{H} 0$ is accepted or $\mathrm{H} 1$ is rejected). The following are the results of the hypothesis test on figure 2 .

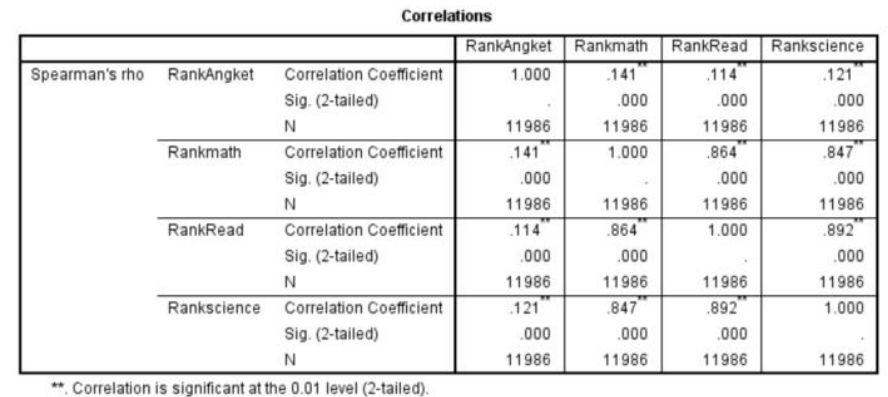

Fig. 2. Result hyphotesis from SPSS output.

Based on the SPSS output, the significance value of the correlation between developing students' metacognition and Mathematics learning outcomes is 0.00 . Because the significance value is $<0.05$ then $\mathrm{H} 0$ is rejected or $\mathrm{H} 1$ is accepted. This means that there is a significant correlation between developing students' metacognition and Mathematics learning outcomes. Furthermore, the correlation coefficient number is 0.141 . The positive value of correlation coefficient number means that the relationship between the two variables is unidirectional. In other words, fostering student metacognition also increases the Mathematics learning outcomes. However, the strength of the relationship (correlation) between variables is only 0.141 , which means the strength of the relationship, is very weak.

Moving on to the second dependent variable, the SPSS output resulted in the significance value of the relationship between developing students' metacognition and Reading learning outcomes is 0.00 . Because the significance value is $<0.05$ then $\mathrm{H} 0$ is rejected or $\mathrm{H} 1$ is accepted. This means that there is a significant correlation between developing students' metacognition and Reading learning outcomes. Furthermore, the correlation coefficient number is 0,114 . The positive value of correlation coefficient number means that the relationship between the two variables is unidirectional. In other words, fostering student metacognition also increases the Reading learning outcomes. However, the strength of the relationship (correlation) between variables is only 0,114 , which means the strength of the relationship is very weak. 
The SPSS output for the last dependent variable showed that the significance value of the relationship between developing students' metacognition and Science learning outcomes is 0.00 . Because the significance value is $<0.05$ then $\mathrm{H} 0$ is rejected or $\mathrm{H} 1$ is accepted. This means that there is a significant correlation between developing students' metacognition and Science learning outcomes. Furthermore, the correlation coefficient number is 0,121 . The positive value of correlation coefficient number means that the relationship between the two variables is unidirectional. In other words, fostering student metacognition also increases the Science learning outcomes. However, the strength of the relationship (correlation) between variables is only 0,121, which means the strength of the relationship is very weak.

\section{Discussion}

The hypothesis test explained before concluded that there is a positive and significant correlation between developing students' metacognition and learning outcomes in Mathematics, Reading and Science. The results of learning Mathematics, Reading, and Science were taken from the results of PISA 2018. The results of this study are in line with the research conducted by Safitri, et al [13] showing that "students with very good metacognition and students with good metacognition are classified as moderately good in solving PISA problems, because students have yet to be able to maximize their metacognition potential fully, while students with poor metacognitive skills are classified as poor in solving PISA problems because almost all aspects of metacognition are not utilized well."

In addition, utilizing the ability of metacognition can help students in solving problems in a subject. This is further explained in the research by Nurhayati, et al [14] stating that students who can make good use of their metacognition abilities are able to solve mathematical problems well. On the contrary, students who cannot use their metacognition abilities well are not able to solve mathematical problems well either.

Students who are more aware of the metacognition process get better result in their learning outcomes. This is because students who are aware of their metacognition abilities will think better and strategically than students who are not aware. Shalihah's research [3] states that "if metacognition awareness is realized, then a person can lead his mind by designing, monitoring, controlling and evaluating what one learns". Furthermore, students' metacognitive knowledge influences critical thinking skills. This is consistent with the results of the research conducted by Kemalawati et al [15] which concluded that metacognition strategies affect student learning outcomes and critical thinking skills.

The result of this study showed that "the strength of the correlation between the independent variable (developing students' metacognition) and the dependent variables (the results of learning Mathematics, Reading, and Science) is very weak". This is partly because many Indonesian students think that intelligence is something that cannot change. This further proven in the infographic on the results of PISA 2018, which pointed that "most students believe that abilities and intelligence can be developed over time. But at least $60 \%$ of students in the Dominican Republic, Indonesia, Kosovo, the Republic of North Macedonia, Panama and the Philippines agreed or strongly agreed that intelligence is something that cannot change very much" [16]. The Indonesian students' answers to the statement "your intelligence is something about you that you can't change very much" in the questionnaire are as follow: strongly disagree $(10.2 \%)$, disagree $(24.3 \%)$, agree $(43.8 \%)$, and strongly agree $(21.7 \%)$.

With the belief that "intelligence cannot be changed very much", the efforts or "struggles" of most Indonesian students to improve their intelligence are also low, because they believe that these efforts will not succeed in increasing their intelligence. The mindset that "intelligence cannot be changed very much" should be changed to "intelligence can be developed over time" because Dilalla [17] states that various studies show that intelligence development is indeed $50 \%$ inherited from parents, but another $50 \%$ beside genetic influence is environmental influences. Therefore, it is not something that cannot be changed or fostered and developed over time.

Environmental influences are very important in shaping the cognitive development of children. Environmental influences include teachers, events that present challenges and possibilities, and peers. Rinaldi and Smith [18] stated that children's brains adapt more efficiently to requests that come from their environment. Children may obtain genetic influence from their parents, and that needs to be sharpened from time to time, too. Environmental influence especially from teachers on a child's intelligence is also very crucial. Thus, teachers have to be able to foster the development of their students' metacognition and provide tasks that could encourage children to sharpen their critical thinking abilities and problem solving skill. Besides that, peers also have significant influence in children development. They can bring either positive influences, which of course can improve their intelligence abilities, or negative influences, which can worsen it over time if not managed well.

\section{CONCLUSION}

Based on the results above, it can be concluded that (i) there is a positive and significant correlation between developing students' metacognition and Mathematics learning outcomes with a correlation coefficient of 0.141 , (ii) there is a positive and significant correlation between developing students' metacognition and Reading learning outcomes with a correlation coefficient of 0.114 , (iii) there is a positive and significant correlation between developing students' metacognition and Science learning outcomes with a correlation coefficient of 0.121 . However, the strength of the relationship (correlation) between the variable 'developing students' metacognition' and the variables 'the results of Mathematics, Reading, and Science learning' is very weak. One of the reasons is due to many Indonesian students think 
that intelligence is something that cannot change. This makes students to be less motivated to improve their competence.

Based on the conclusions above, the following are some suggestions made to improve students' metacognition: (i) The government through Ministry of Education and Culture should issue regulations and their implementation concepts related to the fostering of students' metacognition; (ii) Lembaga Penjamin Mutu Pendidikan/LPMP (Educational Quality Assurance Institution), education offices, Musyawarah Guru Mata Pelajaran/MGMP (Subject Teachers Meeting), Kelompok Kerja Guru/KKG (Teachers Working Group), and other teacher development organizations can conduct training with practice regarding the learning process to foster students' metacognition; (iii) Teachers, with the support of principals and supervisors, should apply a learning process that can foster students' metacognition and also motivate and assure students that intelligence is something that can be changed and developed. Some of the ways teachers can motivate students include giving positive feedback to show appreciation to students' work even if there is a mistake. Teachers should be able to show students the mistakes they make and how to correct it, and to show them their weak subject and help them improve it. This help and guidance should be in practical steps that students can follow in order to improve their learning achievements. Furthermore, some of the ways teacher can foster students' metacognition are by following the indicators given in PISA, which are setting clear goals for students' learning, asking questions to check students' understanding, presenting a short summary of the previous lesson in the beginning of each lesson, telling students the subject matter they have to learn, giving feedbacks about students' strength in each subject, telling students areas to be improved, and telling them how to improve their performances.

\section{ACKNOWLEDGMENT}

Thank you to the Head of the Center for Policy Research Research, Development, and Book Board - Ministry of Education and Culture for giving us the opportunity and motivation to write this research paper.

\section{REFERENCES}

[1] OECD, "What is PISA?", PISA 2018 Assessment and Analytical Framework, OECD Publishing, Paris, 2019.
[2] J.A.C. Hattie, A synthesis of over 800 meta-analyses relating to achievement. London and New York: Education Endowment Foundation, 2009

[3] U. Shalihah, "Membangun Metakognisi Siswa Dalam Memecahkan Masalah Matematika,” Jurnal Ta'allum, vol. 04, no. 1, pp. 83-100, 2016.

[4] S. Syam, U. Rahman, and Nursalam, "Pengaruh Pengetahuan Metakognisi an Gaya Belajar Visual Terhadap Kemampuan Pemecahan Masalah Matematika Siswa Kelas IX SMP Negeri 2 Barombong Kabupaten Gowa," Jurnal Matematika dan Pembelajaran, vol. 4, no. 2, pp. 231-244, 2016.

[5] Desmita, Psikologi Perkembangan Peserta Didik. Bandung: Remaja Rosdakarya, 2014

[6] S.D. Amri, Proses Pembelajaran Inovatif dan Kreatif Dalam Kelas Jakarta: Prestasi Pustaka, 2010.

[7] I. Koc and M. Kuvac, "Preservice Science Teachers' Metacognitive Awareness Levels," European Journal of Education Studies, vol. 2, issue. 3, 2016

[8] R. Chrobak, Metacognition Didactic Tools In Higher Education. Buenos Aires: Comahue National University, 1999.

[9] N. Alfiyah and T.Y.E. Siswono, "Identifikasi Kesulitan Metakognisi Siswa dalam Memecahkan Masalah Matematika," Mathedunesa Jurnal Ilmu Pendidikan Matematika, vol. 3, no. 2, pp. 131-138, 2014.

[10] V.R. Bulu, Kesulitan Metakognisi Siswa dalam Memecahkan Masalah Matematika pada Materi Peluang Ditinjau dari Tipe Kepribadian Tipologi Hippocrates-Galenus Kelas XI MIA 1 SMA Negeri 1 Soe di Nusa Tenggara Timur. In Tesis. Surakarta: Universitas Sebelas Maret, 2015.

[11] Ovan and S.E. Nugroho, "Analisis Kemampuan Literasi Matematika Ditinjau dari Metakognisi Siswa pada Model Pisa-CPS," Unnes Journal of Matematics Education Research, vol. 6, no. 1, pp. 96-102, 2017.

[12] OECD, "Student questionnaire data file," [online]. Retrieved from http://www.oecd.org/pisa/data/2018database/

[13] P.T. Safitri, E. Yasintasari, S.A. Putri, and U. Hasanah, "Analisi Kemampuan Metakognisi Siswa dalam Memecahkan Masalah Matematika Model PISA," Journal of Medives: Journal of Mathematics Education IKIP Veteran Semarang, vol. 4, no. 1, 2020.

[14] H.A. Nurhayati and Hamdani, "Kemampuan Metakognisi siswa dalam Pemecahan Masalah Pada Materi Bangun Datar di Kelas VII SMP," Jurnal Pendidikan dan Pembelajaran Khatulistiwa, vol. 6, no. 3, pp. 113, 2017.

[15] C. Kemalawati, Hasanuddin and Khairil, "Pengaruh Strategi Metakognisi Terhadap Hasil Belajar dan Keterampilan Berpikir Kritis Siswa Pada Materi Sistem Peredaran Darah Manusia Di SMA Negeri Trumon Kabupaten Aceh Selatan,” Jurnal Biotik, vol. 6, no. 2, pp. 110116, 2018.

[16] OECD, "Combined infographics PISA 2018," [online]. Retrieved from https://www.oecd.org/pisa/combined_infographics_PISA2018.pdf

[17] L. Dilalla, "Development of Intelligence: Current Research and Theories," Journal of School Psychology, vol. 38, no. 1, pp. 3-7, 2000.

[18] L. Rinaldi and A. Karmiloff-Smith, "Intelligence as a Developing Function: A Neuroconstructivist Approach,” J Intell., vol. 5, no. 2, p. 18 , 2017. 